\title{
Badania złączy spawanych ze stali P265GH wykonanych z zastosowaniem różnych mieszanek gazowych oraz gatunków drutów spawalniczych
}

\author{
Testing of welded joints made of steel P265GH \\ using various gas mixtures and species welding wires
}

\section{Streszczenie}

W artykule omówiono stan energetyki w Polsce. Scharakteryzowano materiały i technologie stosowane do łączenia stali energetycznych oraz zwrócono uwagę na problematykę ich spawania. Dobrano różne gatunki drutów spawalniczych i gazów osłonowych, z zastosowaniem których wykonano połączenia spawane metodą MAG. Przeprowadzono badania złączy na podstawie wytycznych PN-EN ISO 15614-1. Wykonano statyczne próby wytrzymałości na rozciąganie i zginanie, badania udarności. Dodatkowo przeprowadzono pomiary twardości. Określono makroskopową i mikroskopową budowę połączeń spawanych.

Słowa kluczowe: stan energetyki w Polsce; stale energetyczne; kwalifikowanie technologii; badania materiałowe

\begin{abstract}
This article discusses the state of power generation sector in Poland. Many materials and joining technologies used in power generation sector are characterized. In addition, the article draws attention to the problem of their welding. Different types of welding wires and shielding gases were chosen to make welded joints using using MAG (GMAW) method. The full test procedure of joints was conducted according to the guidelines of PN-EN ISO 15614-1. Statistical tests were carried out to prove tensile, bending and impacts strength and additionally hardness was measured. The samples were analyzed in terms of methodological approaches while macroscopicand microscopic examinations were conducted.
\end{abstract}

Keywords: power generating sector in Poland; energetic steels; qualifying technology; materials research

\section{Wstęp}

\section{Stan energetyki w Polsce}

Obecnie w Polsce eksploatowane są 24 elektrownie systemowe (19 cieplnych i 5 wodnych) [1]. Ponadto funkcjonuje również energetyka rozproszona (elektrownie cieplne i wodne) [1]. W większości są to obiekty oddane do użytku w latach 50.-70. ubiegłego stulecia. Najstarszą elektrownią cieplną jest założona w 1898 r. Elektrownia Jaworzno opalana węglem kamiennym, o mocy elektrycznej zainstalowanej 1345 MWe, osiągająca moc cieplną ok. 50 MWt [2]. Jednocześnie prowadzonych jest 5 inwestycji w nowe bloki cieplne (elektrownie systemowe), o szacowanej łącznej mocy elektrycznej zainstalowanej ok. $7000 \mathrm{MWe}$, których zakończenie planowane jest na lata 2017-2019 [2]. Suma mocy zainstalowanych i osiągalnych w Krajowym Systemie Elektroenergetycznym (na podstawie raportu Polskich Sieci Elektroenergetycznych) przedstawiona jest na rysunku $1[1,3]$.

Analizując powyższe dane oraz opierając się na zasobach literaturowych wyraźnie zauważalnym jest fakt, iż blisko $90 \%$ bloków energetycznych eksploatowanych w Polsce przekroczyło obliczeniowy czas pracy 100000 h, a większość z nich przekroczyła nawet czas eksploatacji 200000 h [3]. Ze względu na widoczny niewielki udział nowych inwestycji w sektorze energetycznym w naszym kraju, tak ważnym jest zapewnienie dyspozycyjności oraz bezpieczeństwa eksploatacji jednostek pracujących. W początkowych założeniach rządu (2007-2015), do 2020 roku w Polsce nastąpić miało blisko dwukrotne zwiększenie zużycia energii elektrycznej, w porównaniu do roku 1997, przy jednoczesnym spadku zużycia węgla kamiennego z 56\% (2007 r.) do ok. 30\% (2020 r.). Wg aktualnych danych, stosunek ten już uległ korekcie, gdyż docelowy spadek zużycia węgla wynosi ok. 40\% (2020 r.) oraz ok. $36 \%$ (2030 r.). Aktualnie nadal podstawowym paliwem dla obiektów energetycznych jest węgiel kamienny i tendencja ta raczej zostanie zachowana. Szacuje się, że obecnie w Polsce aż 92\% energii elektrycznej wytwarzana jest ze spalania węgla kamiennego i brunatnego $[1,3]$.

$\mathrm{Na}$ rozwój technologii energetycznych bezpośrednio wpływają następujące uwarunkowania: techniczno-ekonomiczne (wzrost cen węgla intensyfikuje poprawę sprawności oraz wydłużanie okresów eksploatacji urządzeń nowych i pracujących), ekologiczne (wymuszają podnoszenie sprawności netto, a także ograniczenie emisji szkodliwych związków $\mathrm{NO}_{x}, \mathrm{SO}_{\mathrm{x}}$ oraz $\mathrm{CO}_{\mathrm{x}}$ do atmosfery), prawne oraz czynniki materiałowo-technologiczne [3]. W tym miejscu

Marcelina Kasińska; inż. Krzysztof Towarnicki; dr inż. Tomasz Piwowarczyk; prof. dr hab. inż. Andrzej Ambroziak - Politechnika Wrocławska.

Autor korespondencyjny/Corresponding author. tomasz.piwowarczyk@pwr.edu.pl 
warto zwrócić uwagę na uwarunkowania ekologiczne, bowiem Polska jako kraj członkowski UE powinna dążyć do realizacji celu ilościowego, tzw. „3×20\%” (zmniejszenie emisji gazów cieplarnianych o 20\% w stosunku do 1990 roku, a także zmniejszenie zużycia energii elektrycznej o 20\% w stosunku do szacunków UE do 2020 roku, oraz wzrost udziału odnawialnych źródeł energii do $20 \%$ całkowitego zużycia energii w UE [4]). Ponadto Polska posiada własne cele energetyczne, jak np. zwiększenie udziału odnawialnych źródeł energii do 15\%. W związku z powyższym, kierunki polityki energetycznej są następujące: poprawa efektywności energetycznej, wzrost bezpieczeństwa dostaw paliw i energii, dywersyfikacja struktury wytwarzania energii elektrycznej poprzez wprowadzenie energetyki jądrowej, rozwój wykorzystania odnawialnych źródeł energii (w tym biopaliw), rozwój konkurencyjnych rynków paliw i energii oraz ograniczenie oddziaływania energetyki na środowisko [4].

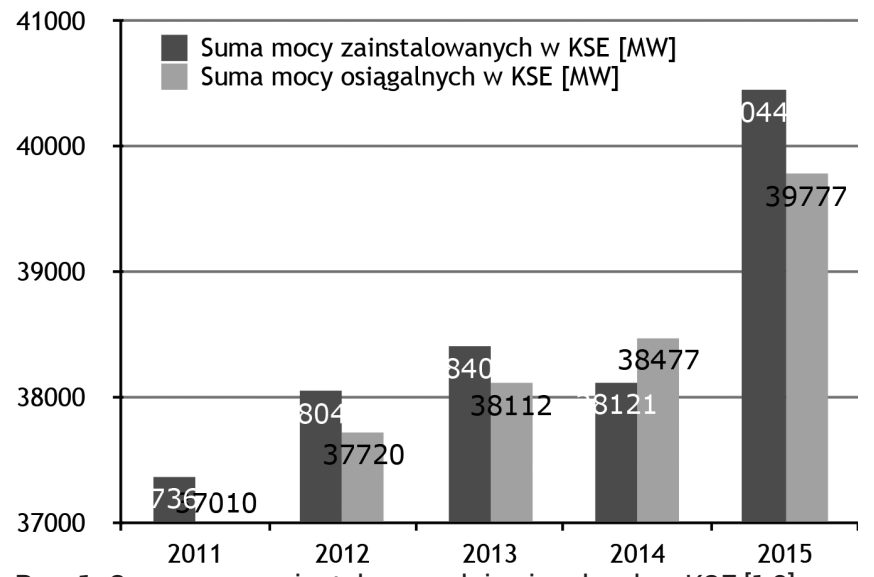

Rys. 1. Suma mocy zainstalowanych i osiągalnych w KSE $[1,3]$

Fig. 1. Sum of installed and achievable capacity in KSE (The National Electricity System) $[1,3]$

Przy uwzględnieniu aktualnej sytuacji energetyki w naszym kraju, przy eksploatacji posiadanych urządzeń ciśnieniowych bardzo ważnym aspektem jest prowadzona diagnostyka elementów, ocena stanu i ich przydatności do dalszej eksploatacji, jak również wyznaczanie trwałości: eksploatacyjnej i resztkowej. W przypadku prowadzenia diagnostyki urządzeń ciśnieniowych dokonywane są badania nieniszczące (PT, MT, UT, badania endoskopowe oraz badania struktury: metoda replik matrycowych i ekstrakcyjnych oraz rentgenowska analiza fazowa izolatu węglikowego), mające na celu pokazanie różnych elementów struktury materiału badanego, które to są niezbędne przy prawidłowym dokona-

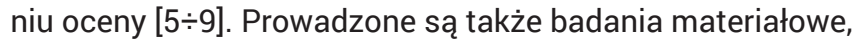
stanowiące główną składową oceny elementu pod kątem jego dalszej eksploatacji i przydatności do bezpiecznej i bezawaryjnej pracy, jak również kwalifikowanie elementów z uwzględnieniem planowania ich badań, napraw, remontów, modernizacji bądź też likwidacji. Do podstawowych czynników powodujących obniżenie trwałości eksploatacyjnej, jak i przedwczesnego niszczenia zaliczamy: błędne założenia projektowe, niewłaściwe wykonanie i montaż oraz warunki

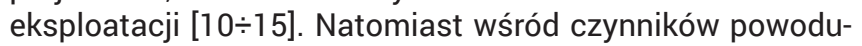
jących niszczenie powierzchni elementów instalacji energetycznych wyróżnia się: przekroczenie temperatury pracy (na którą urządzenie zostało zaprojektowane), grafityzację, kruchość wodorową, korozję wżerową i wysokotemperatu-

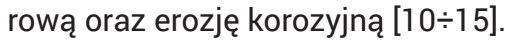

Podstawowym problemem dotyczącym trwałości elementów eksploatowanych w podwyższonej temperaturze jest zjawisko pełzania. Natomiast do wspomnianych czynników materiałowo-technologicznych zaliczamy: trwałość eksploatacyjną złączy spawanych, wykonywanie złączy naprawczych (kombinacje materiałów nowych z eksploatowanymi) oraz dokonywanie zmian konstrukcyjnych w instalacjach po długotrwałej eksploatacji [3]. Istotnym jest zatem, aby podczas opracowywania prognoz trwałości zespołów ciśnieniowych eksploatowanych w warunkach pełzania dysponować charakterystykami właściwości na pełzanie, a także charakterystyki zmian struktury materiału wskutek równoczesnego oddziaływania naprężenia w czasie i temperatury [16 $\div 19]$.

\section{Technologie i materiały stosowane w przemyśle energetycznym}

Analiza tematyki prac prowadzonych aktualnie w zakresie rozwoju materiałów i technologii stosowanych w przemyśle energetycznym, pozwala na wyznaczenie następują-

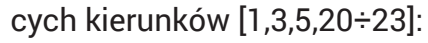

- badania możliwości stosowania nowych materiałów, w tym dla urządzeń pracujących z parametrami nadkrytycznymi,

- rozwój technologii spawalniczych, z zastosowaniem nowatorskich i znanych metod, określanie spawalności materiałów, planowanie procesu spawania oraz szacowanie aspektu ekonomicznego,

- dostosowanie prowadzonych procesów wytwórczych do obowiązujących aktów prawnych;

- projektowanie nowoczesnych obiektów energetycznych z uwzględnieniem aspektów spawalniczych,

- diagnostyka, dopuszczenia do ruchu urządzeń eksploatowanych ponad obliczeniowy czas pracy i związana z tym analiza ryzyka.

Od stali energetycznych oprócz wymaganej wytrzymałości na pełzanie oczekuje się również wytrzymałości mechanicznej, dobrej spawalności oraz odporności na korozję, ale także żądanej granicy plastyczności w temperaturze pokojowej i podwyższonej oraz wytrzymałości na zmęczenie cieplne. Stale stosowane $w$ energetyce powinny ponadto charakteryzować się strukturą, która zapewnia odpowiedni stopień umocnienia (niedopuszczalnym jest umocnienie odkształceniowe, zalecane natomiast jest tworzenie mieszanin faz składających się z ferrytu/austenitu stopowego i dyspersyjnych wydzieleń wę-

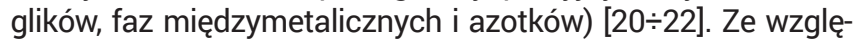
du na charakter pracy urządzeń energetycznych (energetyka przemysłowa i zawodowa) wyróżnia się stale cechujące się żaroodpornością (odporność na działanie gazów utleniających w wysokiej temperaturze) oraz żarowytrzymałością (odporność na działanie gazów utleniających w wysokiej temperatu-

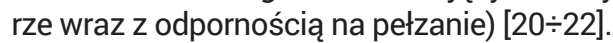

Zgodnie Z PN-EN 10020 stale stosowane do pracy w podwyższonych temperaturach są stalami stopowymi, ale uwzględniając sumaryczne stężenie pierwiastków dokonuje się podziału na stale niestopowe i stopowe [21]. Stale energetyczne klasyfikuje się dokonując podziału na: stale ferrytyczne (stale: niestopowe, średnio- i niskostopowe, 9-12\% $\mathrm{Cr})$, stale austenityczne, stale zaworowe, stale na układy wy-

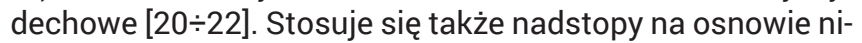
klu, kobaltu i żelaza. Ze względu na stały wzrost cen węgla, a także obostrzenia dotyczące wymagań środowiskowych na przestrzeni ostatnich lat prowadzone są badania nad rozwojem materiałów przeznaczonych na urządzenia energetyczne. Zastosowanie materiałów charakteryzujących się lepszymi właściwościami wytrzymałościowymi pozwala na zwiększenie sprawności urządzeń energetycznych w wyniku efektywniejszego spalania paliw, a tym samym niższą emisję substancji szkodliwych do atmosfery [20 $\div 22]$.

Dzięki bogatym zasobom krajowych ośrodków badawczych opracowane zostały modele matematyczne zjawiska 
pełzania wybranych gatunków stali, w oparciu o utworzone własne charakterystyki materiałów w stanie wyjściowym (dostawy) oraz w okresie po długotrwałej eksploatacji [23]. $\mathrm{Na}$ podstawie opracowanych modeli dokonano symulacji pracy wytypowanych elementów ciśnieniowych. Analizując uzyskane wyniki stwierdzono, że zaproponowane modele w stopniu bardzo dobrym odzwierciedlają dane doświadczalne dla rozpatrywanych elementów.

Wśród zagadnień modernizacyjnych dotyczących urządzeń energetycznych autorzy wskazują na następujące kierunki: optymalizacja stosowanych gatunków materiałów oraz prowadzenie prac nad rozwojem nowych gatunków, dostosowanie do aktualnych norm i przepisów, eliminacja wad konstrukcyjnych, będących wynikiem procesu eksploatacji, dostosowanie do nowych wydajności, obciążeń bądź zmian w procesie technologicznym, a także mierzalna poprawa sprawności. Do typowych uszkodzeń tego typu urządzeń zaliczyć możemy przegrzanie, do którego dochodzi na skutek długotrwałego i nieznacznego, bądź krótkotrwałego i intensywnego przekroczenia wartości temperatury dopuszczalnej, przewidzianej dla zastosowanego gatunku materiału. Przegrzaniu często towarzyszy ubytek grubości ścianki, objawiający się pod postacią erozji i/lub korozji, oraz związany z ww. wzrost naprężeń. Ponadto w przypadku urządzeń długo eksploatowanych, będących pod działaniem naprężeń oraz temperatury wyższej od temperatury granicznej mamy do czynienia z uszkodzeniami pełzaniowymi, zmianą struktury, a także fizycznymi uszkodzeniami (w tym pęknięcia, które dyskwalifikują dany urządzenie z dalszej eksploatacji).

\section{Przedmiot i zakres badań}

Badania przeprowadzono na próbkach wyciętych z wykonanych przy różnych parametrach spawania płyt próbnych, bazując na wymaganiach PN-EN ISO 15614-1. W tym celu wybrano stal gat. P265GH, znajdującą szerokie zastosowanie w branży energetycznej, zwłaszcza w miejscach, gdzie elementy wykonane ze zwykłej stali konstrukcyjnej uległby szybkiemu zniszczeniu. Ze stali tej wykonywane są elementy nie tylko narażone na działanie wysokiej temperatury i ciśnienia medium grzewczego, ale także te poddane działaniu substancji inicjujących korozję. Wstępnie doświadczalnie dobrano parametry spawania. W ramach zaproponowanego programu badań, wykonane zostały złącza doczołowe (BW, $\mathrm{t}=8 \mathrm{~mm}$, ukosowanie $60^{\circ}$, próg $2 \mathrm{~mm}$ odstęp $3 \mathrm{~mm}$ ) oraz złącza teowe (FW, $\mathrm{t}=8 \mathrm{~mm})$, dla mieszanek gazowych i materiałów dodatkowych pokazanych w tablicy I. W tablicy II przedstawione zostały składy chemiczne mieszanek osłonowych zastosowanych do wykonania złączy próbnych. Wszystkie materiały dodatkowe i gazy ochronne do spawania dobrano w oparciu o normy: PN-EN ISO 14175 oraz PN-EN ISO 14341/ER70S-6 wg AWS A5.18.

Bazując na wymaganiach normy PN-EN ISO 15614-1 wykonane zostały badania: VT (100\%), MT (100\%), badania wytrzymałości na rozciąganie poprzeczne, badania wytrzymałości na zginanie poprzeczne, badania udarności oraz badania makroskopowe. Dla stali P265GH należącej do podgrupy 1.1, wg ww. normy nie ma konieczności pomiarów twardości, niemniej w celu uzyskania pełniejszych

Tablica I. Rodzaje złączy w funkcji zastosowanych materiałów dodatkowych do spawania

Table I. Types of joints as a function of fillers used for welding

\begin{tabular}{|c|c|c|c|c|c|c|}
\hline Nr próbki & Złącze & Grubość & Metoda & Drut & Gaz & Ściegi \\
\hline \multirow{2}{*}{1} & P/BW & \multirow{2}{*}{$8 \mathrm{~mm}$} & \multirow{2}{*}{135} & \multirow{2}{*}{$\begin{array}{l}\text { SG2 magmate } \\
\mathrm{d}=1 \mathrm{~mm}\end{array}$} & \multirow{2}{*}{ M21 } & 3 \\
\hline & $\mathrm{P} / \mathrm{FW}$ & & & & & 1 \\
\hline \multirow{2}{*}{2} & P/BW & \multirow{2}{*}{$8 \mathrm{~mm}$} & \multirow{2}{*}{135} & \multirow{2}{*}{$\begin{array}{c}\text { SG2 bronze } \\
\mathrm{d}=1,2 \mathrm{~mm}\end{array}$} & \multirow{2}{*}{ M21 } & 3 \\
\hline & $\mathrm{P} / \mathrm{FW}$ & & & & & 1 \\
\hline \multirow{2}{*}{3} & P/BW & \multirow{2}{*}{$8 \mathrm{~mm}$} & \multirow{2}{*}{135} & \multirow{2}{*}{$\begin{array}{l}\text { SG2 bronze } \\
\mathrm{d}=1,2 \mathrm{~mm}\end{array}$} & \multirow{2}{*}{ M25 } & 3 \\
\hline & $\mathrm{P} / \mathrm{FW}$ & & & & & 1 \\
\hline \multirow{2}{*}{4} & P/BW & \multirow{2}{*}{$8 \mathrm{~mm}$} & \multirow{2}{*}{135} & \multirow{2}{*}{$\begin{array}{l}\text { SG2 magmate } \\
\qquad \mathrm{d}=1 \mathrm{~mm}\end{array}$} & \multirow{2}{*}{ M25 } & 3 \\
\hline & P/FW & & & & & 1 \\
\hline
\end{tabular}

Tablica II. Skład chemiczny i oznaczenie zastosowanych atmosfer ochronnych oraz drutów spawalniczych [24] Table II. Chemical composition and labeling of applied protective atmospheres and welding wires [24]

\begin{tabular}{|c|c|c|c|c|c|c|c|c|c|c|c|c|c|}
\hline \multicolumn{14}{|c|}{ Zastosowane mieszanki gazów osłonowych } \\
\hline \multicolumn{4}{|c|}{ Nazwa handlowa } & \multicolumn{5}{|c|}{ PN-EN ISO 14175} & \multicolumn{5}{|c|}{ Skład } \\
\hline \multicolumn{4}{|c|}{ CORGON 18} & \multicolumn{5}{|c|}{ M21 } & \multicolumn{5}{|c|}{$18 \% \mathrm{CO}_{2}+82 \% \mathrm{Ar}$} \\
\hline \multicolumn{4}{|c|}{ CORGON 2} & \multicolumn{5}{|c|}{ M25 } & \multicolumn{5}{|c|}{$13 \% \mathrm{CO}_{2}+4 \% \mathrm{O}_{2}+83 \% \mathrm{Ar}$} \\
\hline \multicolumn{14}{|c|}{ Zastosowane druty spawalnicze } \\
\hline Drut & C & $\mathrm{Mn}$ & S & $P$ & Si & $\mathrm{Cu}$ & $\mathrm{Ni}$ & $\mathrm{Cr}$ & Al & Mo & $\mathrm{Ti}$ & V & $\mathrm{N}$ \\
\hline $\begin{array}{c}\text { SG2 } \\
\text { MAGMATE }\end{array}$ & 0,08 & 1,5 & 0,013 & 0,011 & 0,88 & 0,029 & 0,02 & 0,021 & - & - & - & - & - \\
\hline $\begin{array}{c}\text { SG2 } \\
\text { BROZNE }\end{array}$ & 0,07 & 1,45 & 0,005 & 0,009 & 0,875 & 0,035 & 0,002 & 0,046 & 0,002 & 0,013 & 0,001 & 0,002 & 0,006 \\
\hline
\end{tabular}


wyników pomiary te zostały przeprowadzone. Wszystkie próbki zostały pobrane wg wytycznych zawartych w normie.

\section{Badania nieniszczące}

Badania wizualne wykonano w zakresie $100 \%$ obszaru spoiny i SWC. Wymiary lica spoiny, tj. wysokość i szerokość dla wszystkich badanych płyt próbnych mieszczą się w poziomie jakości B. Lokalnie zidentyfikowano niezgodności, jak np.: podtopienia (badanie od strony lica) oraz brak przetopu i wyciek w grani (badanie od strony grani). Niezgodności te zakwalifikowane zostały do poziomu jakości D. Występowały one głównie w obszarze przeznaczonym na odpad (25 mm z każdej strony płyty próbnej), stąd nie miały wpływu na wynik pozostałych badań. W zależności od zastosowanego gatunku drutu spawalniczego nie zanotowano istotnych różnic w ilości rozprysków, natomiast zaobserwowano wpływ mieszanki gazowej - dla M21 rozprysk był nieznacznie większy.

Badania magnetyczno-proszkowe przeprowadzono magnesem stałym, zgodnie z wymaganiami PN-EN ISO 17638, w zakresie $100 \%$ złączy spawanych w dwóch wzajemnie prostopadłych kierunkach magnesowania. Zarówno dla złączy doczołowych, jak i teowych, toku oceny nie stwierdzono występowania niezgodności ujętych w normie PN-EN ISO 23278 (rys. 2).
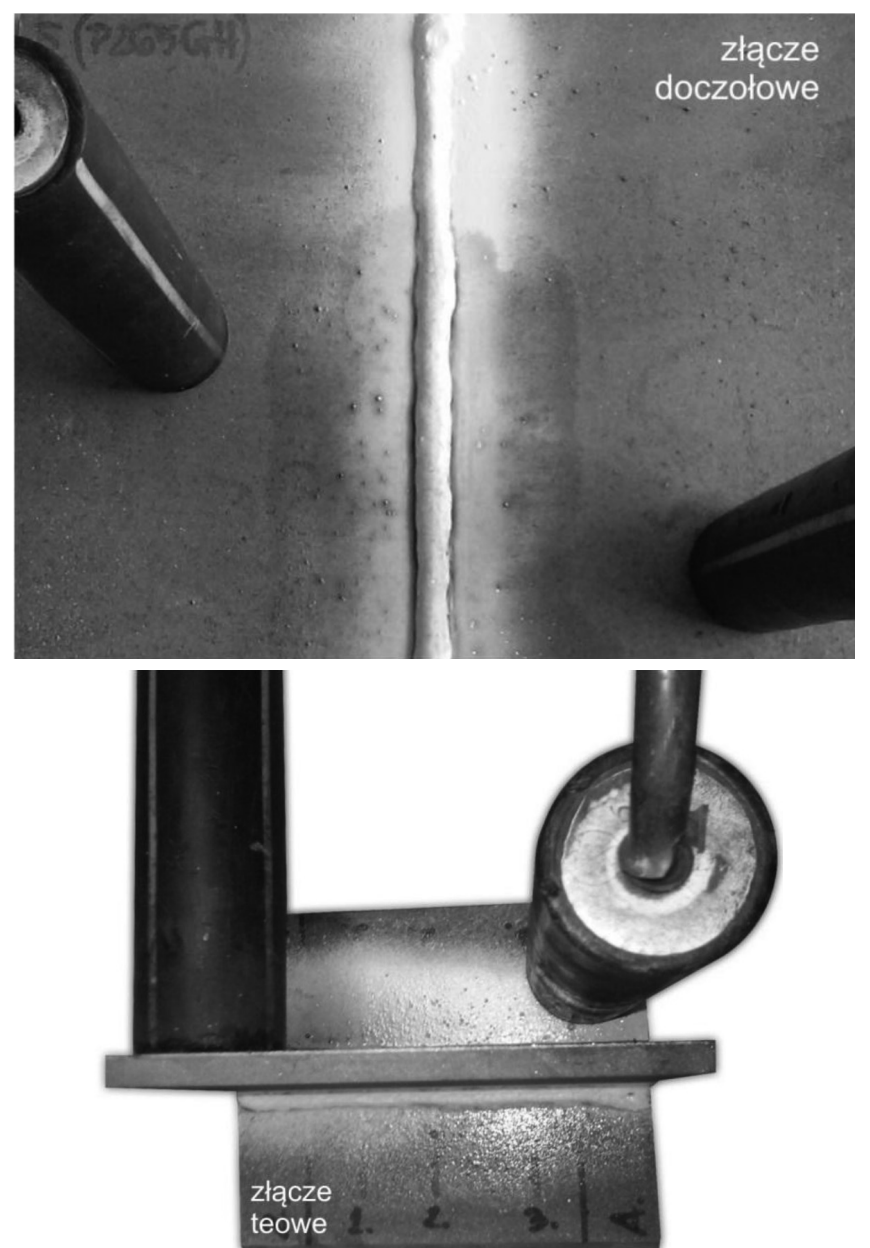

Rys. 2. Badania magnetyczno-proszkowe złączy doczołowych i teowych Fig. 2. Magnetic particle testing of butt and tee joints

\section{Badania niszczące}

Statyczne próby rozciągania oraz zginania poprzecznego złączy spawanych przeprowadzono na maszynie wytrzymałościowej INSTRON model 3369, przy prędkości posuwu belki
$2 \mathrm{~mm} / \mathrm{min}$, odpowiednio $\mathrm{w}$ oparciu o wytyczne PN-EN ISO 4136 i PN-EN ISO 5173.

W przypadku badań wytrzymałości na rozciąganie próbki przygotowano w dwóch wersjach: z frezowanym licem/ granią oraz bez obróbki spoiny. Zniszczenie zasadniczo przebiegało $\mathrm{w}$ materiale rodzimym, poza złączem i strefą wpływu ciepła (rys. 3). W zależności od zastosowanych drutów spawalniczych i gazów osłonowych, otrzymano wytrzymałość na rozciąganie próbek w granicach od $429 \mathrm{MPa}$ (dla próbki nr 4) do $490 \mathrm{MPa}$ (dla próbki nr 1).

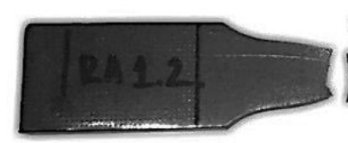
spoina frezowana

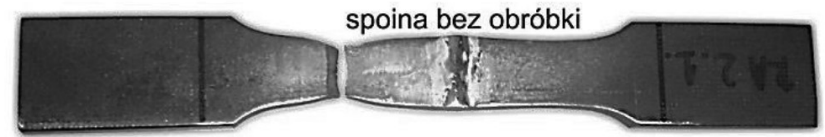

Rys. 3. Obraz próbek po statycznej próbie rozciągania

Fig. 3. Character of samples destruction after tensile strength test

Próbki do badań wytrzymałości na zginanie o wymiarach $8 \times 20 \mathrm{~mm}$, zginano zarówno od strony lica, jak i grani. Zgodnie z wytycznymi normy zastosowano trzpień gnący o promieniu $32 \mathrm{~mm}$ (4t, gdzie t to grubość próbki zginanej), a próbę wykonywano do kąta $180^{\circ}$. Niezależnie od zastosowanych drutów spawalniczych i gazów osłonowych nie zarejestrowano pęknięć i innych niezgodności powierzchniowych na promieniu gięcia. Bezpośrednio po badaniu próbki przylegały do trzpienia w każdej strefie złącza (spoina, SWC, materiał rodzimy), co świadczy o niewielkich różnicach w twardości poszczególnych stref. Przykładową próbkę po badaniu pokazano na rysunku 4.

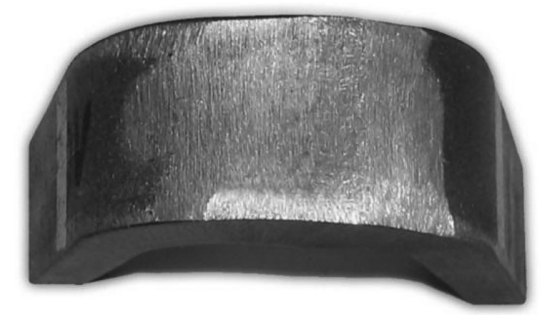

Rys. 4. Wynik technologicznej próby zginania

Fig. 4. Result of bending test

Próbki do badań udarności miały wymiary $5 \times 10 \times 55 \mathrm{~mm}$ z karbem $\mathrm{V}$ na głębokość $2 \mathrm{~mm}$. Analizowano je na młocie Charpy'ego o energii początkowej $300 \mathrm{~J}$. Udarność wyznaczano dzieląc zarejestrowaną pracę łamania przez pole przekroju początkowego próbki. Udarność uzyskana w spoinie i SWC była zbliżona do udarności materiału rodzimego, każdorazowo osiągając wartość $>25 \mathrm{~J} / \mathrm{cm}^{2}$.

\section{Badania makro- i mikroskopowe}

Niezależnie od zastosowanych gat. drutów spawalniczych oraz mieszanek gazowych, nie stwierdzono istotnych różnic w strukturze poszczególnych stref złącza. Każda z analizowanych próbek złączy doczołowych cechuje się poprawną wymiarowo makrostrukturą typu dendrytycznego, z delikatnie zarysowaną SWC oraz liniami wtopienia pomiędzy warstwami spoiny (rys. 5). W przypadku złączy teowych stwierdzono lokalne niezgodności geometryczne części pionowej względem poziomej, wynikające z niewłaściwego dopasowania elementów przed spawaniem (rys. 6). 


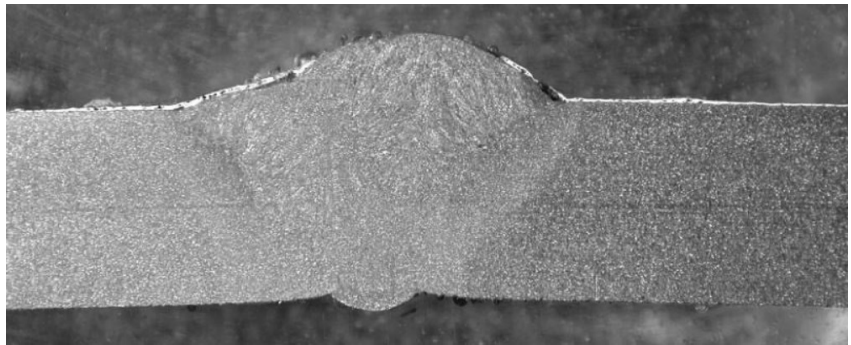

Rys. 5. Makrostruktura złącza doczołowego ze stali P265GH (próbka nr 3) z widoczną strukturą typu dendrytycznego od strony lica w górnej części materiału spoiny (mikroskop świetlny, pow. x3, trawiono odczynnikiem Adlera)

Fig. 5. Macrostructure of a butt joint of P265GH steel (sample no.3) with visible dendritic structure of side faces at the top of the weld (light microscope, mag. $x 3$, etched reagent Adler)

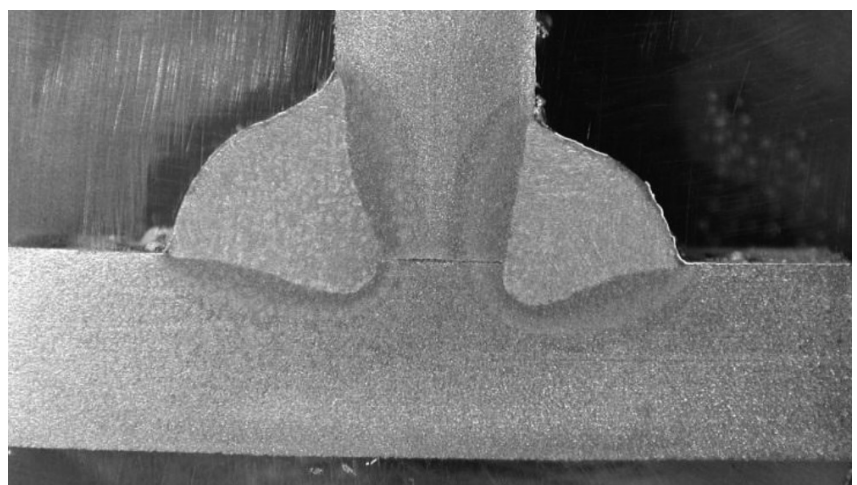

Rys. 6. Makrostruktura złącza teowego ze stali P265GH (próbka nr 1) z widoczną niezgodnością geometryczną (mikroskop świetlny, pow. x3, trawiono odczynnikiem Adlera)

Fig. 6. Macrostructure of fillet joint of steel P265GH (sample no. 1) with visible geometric incompatibility

(light microscope, mag. x3, etched reagent Adler)

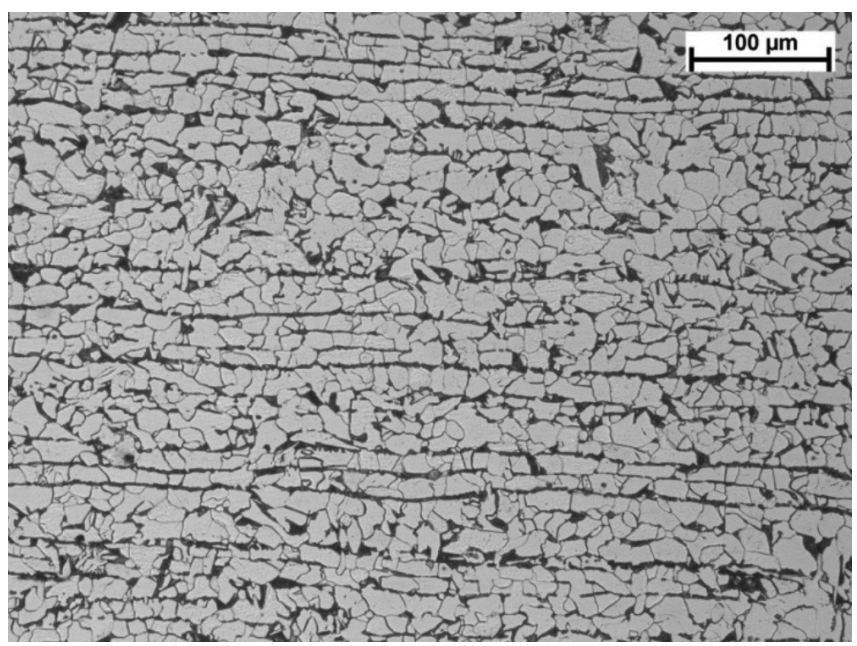

Rys. 7. Mikrostruktura materiału rodzimego

Fig. 7. Microstructure of base material

Mikrostruktura materiału rodzimego została pokazana na rysunku 7 . Widoczna jest pasmowa struktura ferrytyczno-perlityczna, z ziarnami ferrytu (zbliżonymi do równowagowych) oraz dyspersyjnymi ziarnami perlitu.

$\mathrm{Na}$ rysunku 8 pokazana została mikrostruktura materiału spoiny. Widoczna jest struktura nierównowagowego (iglastego i ziarnistego) ferrytu w osnowie quasi-eutektoidu. Miejscami widoczny jest ferryt o budowie bainitycznej.

Mikrostruktury złączy doczołowego oraz teowego w SWC (zbliżone pod względem budowy) pokazane są na rysunkach 9 oraz 10. Od strony materiału spawanego (oznaczenie 1, rysunek 11) widoczna jest struktura nierównowagowego ferrytu w osnowie quasi-eutektoidalnej. W materiale spoiny (oznaczenie 2, rysunek 10) widoczna jest drobnodyspersyjna nierównowagowa mikrostruktura ferrytyczno-perlityczna. Struktura ta jest bardziej zbliżona do struktur równowagowych niż struktura obserwowana w materiale łączonym. $\mathrm{Na}$ rysunku 10 widoczna jest mikrostruktura materiału łączonego (oznaczenie 1) zbliżona do troostytu, otoczona wydzieleniami ferrytu na granicach ziaren, częściowo o budowie bainitycznej. W strefie wtopienia od strony materiału spoiny (oznaczenie 2, rysunek 10) widoczne jest zróżnicowanie składu chemicznego tego obszaru w postaci wąskiego paska struktury ferrytu, która to $\mathrm{w}$ miarę oddalania się od linii wtopienia, przechodzi w nierównowagową strukturę ferrytyczno-perlityczną. Różnice w budowie mikrostrukturalnej spoiny i materiału rodzimego wynikają z relatywnie niższej zawartości węgla w drucie spawalniczym. Natomiast różnice mikrostruktur obserwowanych w spoinach wykonanych z zastosowaniem różnych materiałów dodatkowych są nieznaczne. Wynika to z faktu, że w procesie spawania użyte zostały mieszanki i druty spawalnicze dedykowane dla łączonego gatunku materiału (P265GH), mające zbliżone składy chemiczne.

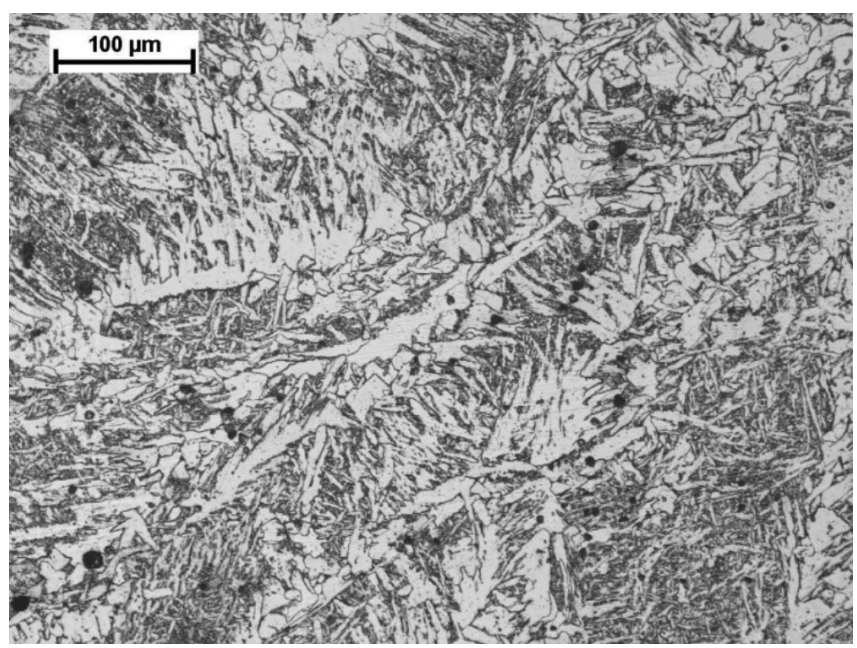

Rys. 8. Mikrostruktura spoiny, próbka nr 3

Fig. 8. Microstructure of weld, sample no. 3

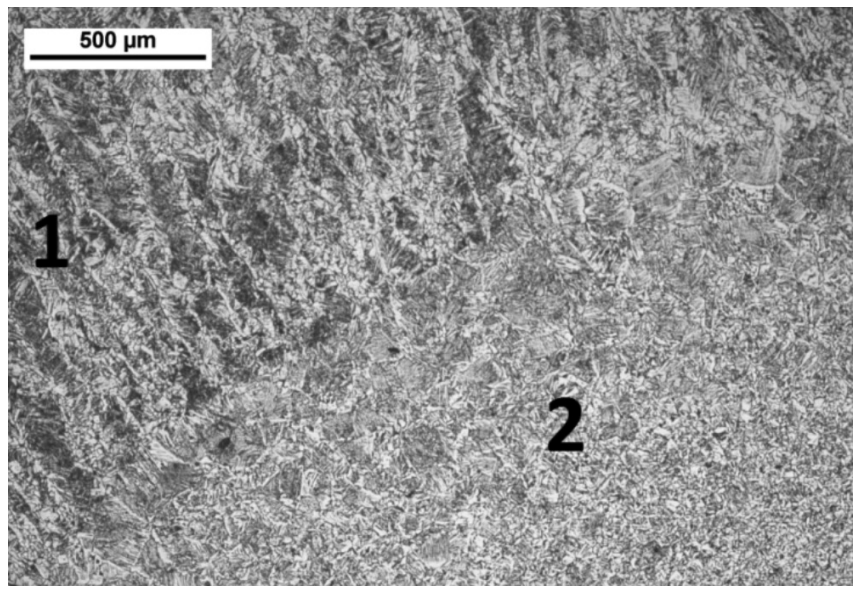

Rys. 9. Mikrostruktura SWC złącza doczołowego, próbka nr 3 Fig. 9. Microstructure of HAZ in butt joint, sample no. 3

\section{Pomiary twardości}

Stal P265GH zaliczana jest do grupy materiałowej $1.1 \mathrm{wg}$ ISO/TR o granicy plastyczności Re $\leq 275 \mathrm{MPa}$, zatem stal ta nie jest wrażliwa na utwardzenie SWC. Dopuszczalna wartość maksymalna twardości (HV10) dla tego gatunku materiału, bez obróbki cieplnej wynosi 380 (z obróbką cieplną 320) 
[25]. W tablicy III zaprezentowane zostały wyniki pomiarów twardości przy obciążeniu 49 N (HV 5) dla trzech stref złączy doczołowych i teowych. Zaobserwowano wzrost twardości w SWC średnio o około 30 oraz spoinie średnio o około 40-50 w porównaniu z materiałem rodzimym, jednak wartości te są nadal bezpieczne i nie zagrażają funkcjonalności złącza.

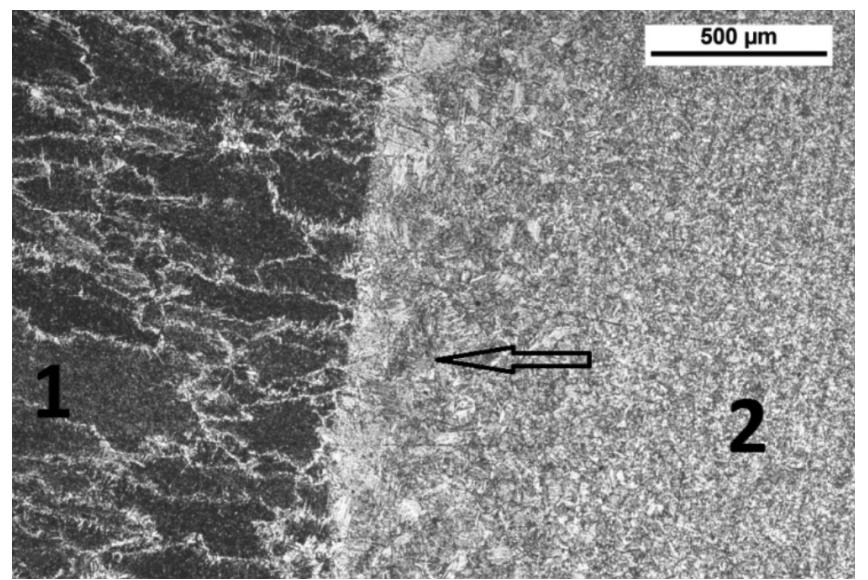

Rys. 10. Mikrostruktura SWC złącza teowego, próbka nr 1 Fig. 10. Microstructure of HAZ in fillet-joint, sample no. 1
Tablica III. Wyniki pomiarów twardości HV5 dla trzech stref złączy doczołowych i teowych

Table III. Results of hardness measurements HV5 for three zones of butt and fillet joints

\begin{tabular}{|c|c|c|c|c|c|c|}
\hline \multirow{2}{*}{ Nr próbki } & \multicolumn{3}{|c|}{ Złącza doczołowe } & \multicolumn{3}{c|}{ Złącza teowe } \\
\cline { 2 - 7 } & MR & S & SWC & Mr & S & SWC \\
\hline 1 & 167 & 212 & 190 & 160 & 238 & 201 \\
\hline 2 & 160 & 204 & 196 & 163 & 240 & 245 \\
\hline 3 & 153 & 193 & 175 & 160 & 230 & 242 \\
\hline 4 & 159 & 204 & 181 & 166 & 234 & 210 \\
\hline
\end{tabular}

\section{Podsumowanie}

Cel badań, jakim była analiza właściwości połączeń spawanych stali energetycznej P265GH, wykonanych w funkcji różnych drutów spawalniczych i mieszanek gazów osłonowych, został zrealizowany. Przeprowadzone badania nieniszczące i niszczące potwierdziły przydatność stosowanych materiałów dodatkowych do wykonywania funkcjonalnych połączeń. Nieznaczne różnice w składach chemicznych, zarówno spoiw, jak i atmosfer ochronnych, nie wpłynęły wyraźnie na uzyskane właściwości złączy. Przeprowadzone badania wizualne dały wynik pozytywny określony poziomem jakości B. Wystąpiły nieliczne lokalne niezgodności typu: podtopienia, braki przetopu oraz wycieki od strony grani (usytuowane głównie w obszarach przeznaczonych na odpad, nieuwzględnionych przy badaniach określających własności wytrzymałościowe). Poprawność badań wizualnych potwierdzają badania magnetyczno-proszkowe, gdzie na podstawie uzyskanych wyników nie stwierdzono występowania niezgodności ujętych w PN-EN ISO 23278. W przypadku próby rozciągania, zniszczenie zwykle miało miejsce w materiale rodzimym, poza obszarem spoiny i SWC (zarówno dla próbek z pozostawionym nadlewem, jak i frezowanych). Także w toku próby zginania nie zaobserwowano wystąpienia pęknięć bądź innych niezgodności powierzchniowych na promieniu gięcia. Zauważalne było natomiast bezpośrednie przyleganie próbek do promienia gnącego tuż po badaniu, co świadczy o niewielkich różnicach twardości dla poszczególnych stref, co zostało potwierdzone badaniami twardości właśnie. Z puli badań niszczących przeprowadzono również badania udarności. Przy obserwacji makrostruktury złączy doczołowych każdorazowo stwierdzono poprawną wymiarowo makrostrukturę typu dendrytycznego. W przypadku złączy teowych stwierdzono występowanie lokalnych niezgodności geometrycznych, będących wynikiem niewłaściwego dopasowania elementów przed spawaniem. Dla wybranych złączy scharakteryzowano również mikrostruktury poszczególnych stref złącza. Pakiet przeprowadzonych badań był tożsamy z kwalifikowaniem technologii spawania wg PN-EN ISO $15614-1$.

\section{Literatura}

[1] http://www.pse.pl

[2] http://www.rynek-energii-elektrycznej.cire.pl

[3] J. Dobrzański: Materiałoznawcza interpretacja trwałości stali dla energetyki, Open Access Library, Volume 3, 2011, s. 1-228.

[4] Polityka energetyczna Polski do 2030 roku, Ministerstwo Gospodarki, Załącznik do uchwały nr 202/2009 Rady Ministrów, Warszawa 2009.

[5] J. Adamiec, M. Januszkiewicz: Ocena odporności na korozję wysokotemperaturową złączy spawanych laserowo rur ożebrowanych wykonanych ze stopów niklu, Przegląd Spawalnictwa, Vol 87, No 10, 2015

[6] J. Dobosiewicz, E. Zbroińska-Szczechura: Ocena stopnia zużycia ciśnieniowych elementów kotłów pracujących w warunkach pełzania, Energetyka nr 12, s. 917-922, 2007.

[7] J. Trzeszczyński: Monitorowanie pracy urządzeń cieplno-mechanicznych jako istotny element prognozowania ich żywotności w ostatniej fazie wydłużonej eksploatacji, Energetyka nr 12, s. 129-131, 2009.

[8] A. Jasiński: ElP-online.pl, nr 1(2), s. 8-12, 2014

[9] J. Dobosiewicz, E. Zbroińska-Szczechura: Wytyczne oceny spoin, kolan rurociągów i komór pracujących w warunkach pełzania, Energetyka nr 12, s. 123-128, 2009

[10] J. Dobrzański, H. Paszkowska, B. Kowalski, J. Wodzyński: Diagnostyka urządzeń energetycznych pod działaniem ciśnienia w podwyższonej temperaturze, Prace IMŻ nr 1, s. 33-41, 2010.

[11] J. Dobrzański: Diagnostyka uszkodzeń elementów ciśnieniowych urządzeń energetycznych w ocenie przyczyn powstawania awarii na podstawie badań materiałowych, Prace IMŻ nr 2, s. 36-45, 2009 .

[12] A. Zieliński, J. Dobrzański: Ocena stanu i przydatności do dalszej pracy materiału rurociągów parowych eksploatowanych powyżej obliczeniowego czasu pracy, Prace IMŻ nr 3, s. 42-54, 2013.

[13] J. Dobrzański, M. Cieśla: Wpływ długotrwałej eksploatacji na zmianę właściwości użytkowych materiału komór przegrzewacza pary pracujących w warunkach pełzania wykonanych z martenzytycznej stali X20CrMoV1 1-1, Prace IMŻ nr 4, s. 23-38, 2013.
[14] J. Dobrzański, A. Zieliński, H. Paszkowska: Wyznaczanie trwałości resztkowej i czasu dalszej bezpiecznej pracy na przykładzie materiału rodzimego złącza spawanego, Prace IMŻ nr 1, s. 9-25, 2009.

[15] J. Dobrzański, A. Zieliński, H. Purzyńska, M. Dziuba-Kałuża: Trwałość eksploatacyjna materiału elementów pracujących $w$ warunkach pełzania w energetycznych urządzeniach wysokociśnieniowych, Prace IMŻ nr 2, s. 158-167, 2010.

[16] J. Dobrzański, A. Zieliński, H. Purzyńska, M. Dziuba-Kałuża: Badania nowych materiałów na elementy kotłów o nadkrytycznych parametrach pracy, Prace IMŻ nr 2, s. 106-111, 2015.

[17] J. Dobrzański, A. Zieliński, H. Purzyńska: Charakterystyki materiałowe i metodologia oceny stanu wybranych stali nowej generacji elementów kotłów o nadkrytycznych parametrach pracy, Prace IMŻ nr 3, s. 13-27, 2014.

[18] M. Roskosz, K. Fryczowski, S. Griner, A. Katunin: Analiza możliwości oceny procesu pełzania stali X12CrMoWVNbN10-1-1 na podstawie szumu Barkhausena, Przegląd Spawalnictwa, Vol 86, No 11, 2014.

[20] W. Dudziński, K. Widanka: Ćwiczenia laboratoryjne z materiałoznawstwa, Oficyna Wydawnicza Politechniki Wrocławskiej, 2012

[21] J. Pilarczyk: Poradnik Inżyniera Spawalnictwo t. 1, WNT Warszawa 2014.

[22] M. Blicharski: Inżynieria materiałowa Stal, WNT Warszawa 2010,2012.

[23] J. Dobrzański, P. Duda, L. Mirecki: Modelowanie zjawiska pełzania oraz symulacja pracy wybranych elementów przegrzewacza pary części ciśnieniowej kotła o nadkrytycznych parametrach pracy, Prace IMŻ nr 3, s. 29-40, 22014.

[24] Katalog produktów Linde 2015.

[25] J. Czuchryj, B. Kurpisz: Badania złączy spawanych. Przegląd metod, Wydawnictwo KaBe, Krosno 2009. 